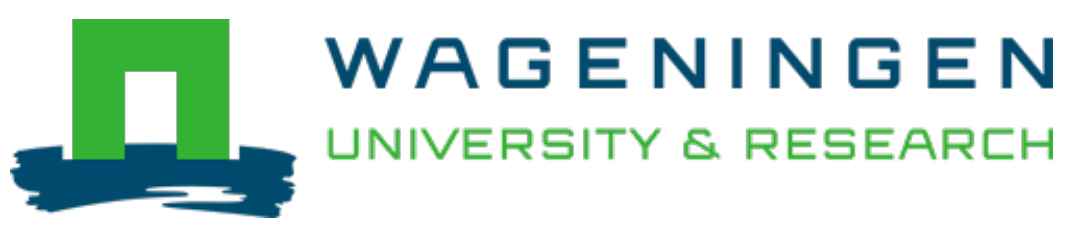

\title{
Learning Apart Together: Towards an Integrated Competence Framework for Sustainable Entrepreneurship in Higher Education
}

\author{
Journal of Cleaner Production \\ Lans, T.; Blok, V.; Wesselink, R. \\ https://doi.org/10.1016/j.jclepro.2013.03.036
}

This article is made publicly available in the institutional repository of Wageningen University and Research, under the terms of article $25 \mathrm{fa}$ of the Dutch Copyright Act, also known as the Amendment Taverne. This has been done with explicit consent by the author.

Article 25 fa states that the author of a short scientific work funded either wholly or partially by Dutch public funds is entitled to make that work publicly available for no consideration following a reasonable period of time after the work was first published, provided that clear reference is made to the source of the first publication of the work.

This publication is distributed under The Association of Universities in the Netherlands (VSNU) 'Article $25 \mathrm{fa}$ implementation' project. In this project research outputs of researchers employed by Dutch Universities that comply with the legal requirements of Article $25 \mathrm{fa}$ of the Dutch Copyright Act are distributed online and free of cost or other barriers in institutional repositories. Research outputs are distributed six months after their first online publication in the original published version and with proper attribution to the source of the original publication.

You are permitted to download and use the publication for personal purposes. All rights remain with the author(s) and / or copyright owner(s) of this work. Any use of the publication or parts of it other than authorised under article $25 \mathrm{fa}$ of the Dutch Copyright act is prohibited. Wageningen University \& Research and the author(s) of this publication shall not be held responsible or liable for any damages resulting from your (re)use of this publication.

For questions regarding the public availability of this article please contact openscience.library@,wur.nl 


\title{
Learning apart and together: towards an integrated competence framework for sustainable entrepreneurship in higher education
}

\author{
Thomas Lans ${ }^{\mathrm{a}, *}$, Vincent Blok ${ }^{\mathrm{b}, 1}$, Renate Wesselink ${ }^{\mathrm{a}, 2}$ \\ ${ }^{a}$ Wageningen University, Education and Competence Studies, P.O. Box 8130, 6700 EW Wageningen, The Netherlands \\ ${ }^{\mathrm{b}}$ Wageningen University, Management Studies, P.O. Box 8130, 6700 EW Wageningen, The Netherlands
}

\section{A R T I C L E I N F O}

\section{Article history:}

Received 26 May 2012

Received in revised form

7 February 2013

Accepted 20 March 2013

Available online 5 April 2013

\section{Keywords:}

Competence

Sustainable entrepreneurship

Higher education

Education for sustainable development

Entrepreneurship education

\begin{abstract}
A B S T R A C T
Sustainable entrepreneurs, i.e. those who proactively facilitate latent demands for sustainable development, are now in higher demand than ever before. Higher (business) education can play an important role in laying the foundation for these sustainable entrepreneurs. Traditionally, however, educational scholars focus either on the issue of education for sustainability or on entrepreneurship education. There is little work which explores and/or crosses the boundaries between these two disciplines, let alone work in which an effort is made to integrate these perspectives. In this article, a competence approach was taken as a first step to link the worlds of education for entrepreneurship and for sustainability because we postulate that both, apparently different, worlds can reinforce each other. Based on a literature review, focus group discussions with teachers in higher education $(n=8)$ and a structured questionnaire among students $(n=211)$, a set of clear, distinct competencies was developed, providing stepping stones for monitoring students' sustainable entrepreneurship development in school-based environments.
\end{abstract}

(ㄷ) 2013 Elsevier Ltd. All rights reserved.

\section{Introduction}

Ninety-three percent of the world's CEOs conceive sustainable development as important to their company's future success (Accenture, 2010). In order to actually fuel the identification, evaluation and exploitation of (business) opportunities for sustainable development, companies are in need of owners, managers and staff-members who are able to recognise sustainability as an opportunity, i.e. as a driver for strategic renewal, innovation and venturing. Although opportunity recognition is a fundamental characteristic of entrepreneurship (Shane and Venkataraman, 2000), entrepreneurialism is often equated with unsustainability. Entrepreneurs are portrayed as money-driven, growth- and production-orientated individuals who pursue purely economic goals. Such a perspective clearly neglects, however, the capacity and intentions of individuals and entrepreneurial firms to create new opportunities in which ecological and societal goals are carefully integrated into viable, profitable and therefore sustainable business models.

\footnotetext{
* Corresponding author. Tel.: +31 (0) 317484343.

E-mail addresses: Thomas.lans@wur.nl (T. Lans), vincent.blok@wur.nl (V. Blok), renate.wesselink@wur.nl (R. Wesselink).

1 Tel.: +31 (0) 317485454 .

2 Tel.: +31 (0) 317484343 .
}

The concept of sustainable entrepreneurship has gained importance over recent years (Schaltegger and Wagner, 2011). The relationship between entrepreneurship and sustainable development has been dealt with through various schools of thought, often resulting in the launching of new types of entrepreneurs, such as the ecopreneur and the social entrepreneur (Schaltegger and Wagner, 2011; Zahra et al., 2009). Whereas the ecopreneur pursues environmental opportunities from an economic point of view, the social entrepreneur has a broader societal perspective (Zahra et al., 2009). For the social entrepreneur, the creation of societal value is the ultimate goal, while economic goals are just a means to reach these societal ends. The term 'sustainable entrepreneurship' has been coined more recently as an overarching way of looking at the contribution of entrepreneurial endeavours to social, ecological and economic aspects: or, in other words, sustainable development (Schaltegger and Wagner, 2011).

Sustainable entrepreneurs seem to combine the best of both worlds, that is, initiating those activities and processes that lead to the identification, evaluation and exploitation of profitable business opportunities (i.e. entrepreneurship) while contributing to sustainable development (Schaltegger and Wagner, 2011; Zahra et al., 2009). In this respect, sustainable entrepreneurship is seen as a way of generating competitive advantage by identifying sustainability as new business opportunities, resulting in new and sustainable products, methods of production or ways of organising business processes in a sustainable way. It is proactive and 
innovation-orientated (Klewitz and Hansen, 2011), which means that sustainable entrepreneurship is not primarily about meeting increasing environmental regulations on national or international levels: rather, it takes (competitive) advantage of the increasing need for sustainably produced products and services that move beyond the level of compliance.

In order to be able to recognise sustainable development as a business opportunity, sustainable entrepreneurs are in need of opportunity recognition skills, but also, for instance, interpersonal skills which enables them to interact with, learn from and adapt to stakeholders (Buysse and Verbeke, 2003; Dunphy et al., 2007). It is likely that these skills, knowledge and attitudes stem from individual competencies, i.e. competencies for sustainable entrepreneurship. It is unlikely that these competencies for sustainable entrepreneurship are developed overnight: they represent elements of entrepreneurship and sustainability which prior research has shown to require higher order learning processes (Cope, 2005; Corbett, 2005; Wals and Jickling, 2002).

Higher education plays an important role in laying the foundation for competence development for sustainable entrepreneurship. Traditionally, however, educational scholars focus either on the issue of education for sustainability or on entrepreneurship education. Whereas entrepreneurship education is traditionally located in the business schools, education for sustainable development often has its origin in the environment education faculty. There is little work from an educational point of view which explores and/or crosses the boundaries of these two disciplines, let alone work in which an effort is made to integrate these perspectives.

In this article we focus on an educational challenge, namely the identification and operationalisation of competencies which clearly go beyond disciplinary knowledge, but which encompass skills, knowledge and attitudes directed at the integration of the worlds of entrepreneurship and sustainability (Gibb, 2002; Wals, 2010). Competencies in general enable successful task performance and problem solving with respect to real-world problems, challenges and opportunities (Barth et al., 2007; Dale and Newman, 2005; Dentoni et al., 2012; Rowe, 2007) on an individual level. Competencies can be viewed as a catalyst for creating a more critical, innovative, and reflexive culture that frequently questions its own routines, assumptions, and guiding principles. This perspective has been applied recently for instance in the work of De Haan (2006), Lambrechts et al. (2013) and Lans et al. (2008). However, their focus was either on sustainable development or on entrepreneurship.

In line with such a competence-perspective (defined as the comprehensive approach in Europe, cf. Wesselink et al. (2010) and Mulder (2012)), this article focuses first on the question: which competencies constitute the heart of entrepreneurship and sustainable development (i.e. sustainable entrepreneurship)? Additionally, considering the specific context of business higher education for sustainable development, the article zooms further in on the question: Which competencies for sustainable entrepreneurship can be clearly identified within the context of higher education?

The article is structured in the following way. Clearly, sustainable entrepreneurship consists of two core concepts: entrepreneurship and sustainability, and the relationship between the two. The article starts by unfolding entrepreneurship and sustainable development in relation to competence, resulting in two broad competence lists. In the second part of this article both competence lists are integrated and operationalised into a higher educational context through two empirical studies, namely focus group discussions with teachers $(n=8)$ and a structured questionnaire among students $(n=211)$. The article ends with a discussion and conclusion of the results.

\section{Theoretical framework}

\subsection{Entrepreneurship and entrepreneurial competence}

A wide diversity of definitions can be found for the terms entrepreneurship and entrepreneur. From the scholarly field of entrepreneurship, many attempts have been made to establish some clarity in this semantic confusion - a discussion which is fed on the one hand by disciplinary inheritance (e.g. economics, sociology, psychology) and on the other hand by pragmatism (e.g. constraints in data collection). Over the last three decades this has resulted in at least three important insights which give direction to the way sustainable entrepreneurship competence, in higher education, can be seen. These insights are discussed briefly below.

Firstly, over the years there has been a growing consensus that a fundamental and distinctive feature of entrepreneurship is the identification and pursuit of business opportunities (Gaglio and Katz, 2001; Shane and Venkataraman, 2000). The identification of opportunities, and the turning of them into ventures, has a long history in entrepreneurship research as one of the most distinct characteristics of the entrepreneur in comparison with other groups (Dutta and Crossan, 2005). Opportunities arise from macroeconomic changes in the environment in which the entrepreneur engages, such as technological, political, social and demographic changes. The entrepreneur with superior personal qualities takes advantage of these changes, resulting in a range of entrepreneurial actions such as introducing new products, new methods of production, new (geographical) markets, and new ways of organising business processes (Schumpeter, 1934). Unlike the Schumpeterian innovation perspective on opportunities, the Kirznerian view (originating from the economist Israel Kirzner) on opportunities suggests that opportunities are not simply identified by the person with superior qualities but 'arise out of the entrepreneur's alertness to information asymmetries existing in the economy' (Dutta and Crossan, 2005). The identification of opportunities is thus seen as a matter of entrepreneurial alertness which highlights the idiosyncratic individual knowledge base of the entrepreneur (Gaglio and Katz, 2001). Hence, depending on the underlying theoretical assumptions of the concept of opportunity, different aspects of the opportunity process, ranging from prior knowledge to creativity, are placed at its core. What is interesting, is that in more recent work on opportunity identification and pursuit, some authors regard these different viewpoints as complementary, rather than as mutually exclusive (Chiasson and Saunders, 2005; Dutta and Crossan, 2005). No matter which perspective is taken, putting entrepreneurial opportunities at the heart of the definition of entrepreneurship implies a focus on new products, services and processes for the market or industry rather than a narrow perspective of becoming self-employed or creating new ventures.

Secondly, one of the most pervasive myths regarding entrepreneurs is that they are born with specific characteristics which are difficult, if not impossible, to develop. Until the 1990s, this was a school of thought known as the 'trait approach' to entrepreneurship (Gartner, 1989). Entrepreneurs could be discerned from nonentrepreneurs on the basis of special traits, such as locus of control, which would also explain their success. Apart from the question of how one could investigate these differences from a methodological point of view, such a perspective on entrepreneurship is difficult to defend, considering the empirical support which is found for the effects of experience (e.g. novice versus expert entrepreneurs) (Baron and Ensley, 2006) and entrepreneurship education on entrepreneurial success (Pittaway and Cope, 2007). The move away from more stable personality constructs has cleared the path for studies on more dynamic, learnable constructs, such as capabilities (on the company level) and competence (on the 
individual level). For instance, there is consistent support for companies with an entrepreneurial orientation on financial success (Lumpkin and Dess, 1996, 2001). Also entrepreneurial competencies on the individual level were found to be related to entrepreneurial success (Baron and Markman, 2003; Baum and Locke, 2004; Baum et al., 2001; Chandler and Jansen, 1992; Ucbasaran et al., 2008). Moreover, it has been reported that entrepreneurship education has a positive influence on specific entrepreneurial competencies. For instance DeTienne and Chandler (2004) found that targeted entrepreneurship education led to the identification of more opportunities and more innovative opportunities. Similar, Muñoz et al. (2011) reported that entrepreneurship education develops the student's competence in the identification of opportunity.

Finally, whereas the entrepreneur is often portrayed as the (Schumpeterian/Kirznerian) heroic individual, scholars of entrepreneurship increasingly question the focus on the individual without consideration of the social (Dimov, 2007). The importance of social interactions in entrepreneurship is convincingly illustrated in social capital network literature (Arenius and Clercq, 2005). Networks play an important role in entrepreneurial processes and outcomes. Networks are important for spotting new opportunities, for acquiring resources, such as finance or employees, and, in case of brand new services or products, for gaining legitimacy for their new products or services (Aldrich and Zimmer, 1986).

In spite of the fact that the outlined developments have brought to light the significance of the concept of entrepreneurial competence, the demarcation of the concept remains far from clear. As stated, competence in the entrepreneurship literature is used as an individual construct as well as a company-level construct (e.g. entrepreneurial orientation, dynamic capability) (Lumpkin and Dess, 1996; Teece et al., 1997). Furthermore, entrepreneurial competence is operationalised in various different ways, ranging from broad latent constructs (e.g. Man et al., 2002) to studies in which competencies are equated with years of experience or levels of education (Colombo and Grilli, 2005). Studies regarding entrepreneurial competence at an individual level can be found in generic small business literature (Man et al., 2002; Sadler-Smith et al., 2003; Wu, 2009) as well as in specific sector studies such as the agri-food sector (Lans et al., 2011; Nuthall, 2006; Phelan and Sharpley, 2012), health care (Guo, 2009; Mackey, 2005; Rubino and Freshman, 2005), biotechnology (Gurău, 2006) and hospitality and tourism (Wagener et al., 2010; Zapalska et al., 2004). What is clear from all these studies is that entrepreneurial competencies are (in) directly related to business success (Baum and Locke, 2004; Camuffo et al., 2012; Chandler and Jansen, 1992), that it is necessary to differentiate between generic and more context-specific or industry specific entrepreneurial competencies (Ahmad et al., 2011), and that experience during early adolescence plays an important role in the foundation and development of entrepreneurial competence (Obschonka et al., 2011a,b). In line with the previously described view on opportunities, entrepreneurial competence is thus defined as the ability to identify and pursue entrepreneurial opportunities within a specific position and context.

Due to the outlined diversity in the type of studies and contexts, the list of skills, attitudes and other characteristics associated with entrepreneurial competence is endless. Reviews by Man et al. (2002) and Mitchelmore and Rowley (2010), besides several empirical studies, have been conducted to create more clarity in the larger domain of entrepreneurship competence. Although the exact demarcation of entrepreneurial competence remains problematic due to mutual dependency and context specificity, five generic competencies are frequently described in all these studies. Based on the above mentioned theoretical framework and the mentioned (review) studies, specifically on entrepreneurial competence, we regard these competencies as the backbone of entrepreneurial competence. They are described below in more detail.

1. Opportunity competence. Unquestionably, entrepreneurial competence relates to the identification of opportunities (Shane and Venkataraman, 2000). What, post-hoc, may be described as a real entrepreneurial opportunity is, in its rudimentary form, often an ill-defined market need, a technology or invention for which no market has yet been defined, or an idea for a product or service (Ardichvili et al., 2003). As we have seen, depending on the underlying theoretical assumptions of the opportunity concept (Companys and McMullen, 2007; DeTienne and Chandler, 2004), different aspects can be placed at the core of this competence, such as the individual's superior opportunity search and assessment strategies (Chandler and Jansen,1992) or entrepreneurial alertness - being able to spot opportunities, for instance in business relationships, in the market and in the broader environment (Gaglio and Katz, 2001). As we see it, opportunity competence is more than just opportunity recognition; it focuses on the systematic development of adequate solutions to problems, i.e. emphasising a more constructed view on opportunities, thus putting perception, interpretation and construction at the heart of opportunity identification.

2. Social competence. This set refers to interactions with others (Baron and Markman, 2003; Baron and Tang, 2009; Lans et al., 2011; Man et al., 2002; Mitchelmore and Rowley, 2010). As explained, networks play an essential role in the opportunity development process, fostering the generation and development of new ideas, and in gaining resources and legitimacy. Since external contacts and relationships are often established from scratch, the ability to build up and maintain relationships, externally as well as internally, seems to be important.

3. Business competence. The reviews of Mitchelmore and Rowley (2010) as well as the Man et al. (2002) refer to the importance of business/management competence which involves the ability to develop, organise and coordinate management systems. Whereas opportunity competence mainly focuses on exploration (e.g. search, experimentation, discovery), business competence emphasises exploitation (refinement, choice, implementation and execution). This competence involves the organisation of different internal, external, human, physical, financial and technological resources as well as setting, evaluating and implementing the strategies of the firm (i.e. planning and control).

4. Industry-specific competence. The fourth area involves technical knowledge (know-how) and market knowledge (know-what). Whereas the former is the technological knowledge involved in a specific job or industry, the know-what includes information about the market. There is an abundance of empirical work which shows the importance of industry-specific knowledge and experience for the successful exploitation of entrepreneurial opportunities (Baum et al., 2001; Colombo and Grilli, 2005; Ucbasaran et al., 2008).

5. Entrepreneurial self-efficacy. The fifth area is a broad domain of meta-level competencies: individual-level constructs which influence other competencies positively (Le Deist and Winterton, 2005), rather than being an element of it (Markman, 2007). This domain comprises those constructs which have close conceptual links with more motivational psychological constructs. Recent meta-analysis shows that entrepreneurial self-efficacy in particular (belief in one's own entrepreneurial competence (Bandura, 1982)) is one of the strongest individual level predictors for entrepreneurial success (Rauch and Frese, 2007). More specifically, entrepreneurial self-efficacy concerns a person's belief in his/her own (entrepreneurial) competence. 


\subsection{Sustainability and sustainable development competence}

Since the famous Brundtland Report (World Commision on Environment and Development, 1987), sustainable development is defined as a development 'that meets the needs of the present without compromising the ability of future generations to meet their own needs'. This abstract definition is not only contested by hundreds of more recent alternative definitions, but has given rise to debates on how to operationalise the concept of sustainable development. What is evident from these debates is that sustainability is a shared challenge with regard to economic (profit), social (people) and environmental (planet) goals for many parties in society. An important driver for the increasing societal concern about sustainable development was the publication of the Living Planet Report in 2006 (WWF, 2006), in which it was stated that humanity will be using two planets' worth of natural resources by 2050, if current trends continue. Because human beings are, to a large extent, dependent for their survival upon the continued functioning of natural systems, the awareness of our responsibility with regard to sustainable development has increased significantly ever since. Governments, civil society and citizens feel increasingly obliged to foster sustainability in order to guarantee the quality of life of future generations.

Thus, although there is little dispute about the importance of sustainable development, the concept provides no direct clues about how to move forward. Sustainability is however not only something to act upon, comply with or engage in, but can also be seen as a major source for opportunities (Klewitz and Hensen, 2011; Málovics et al., 2006; Zadek, 2004). The growing interest in sustainable entrepreneurship suggests that sustainability is an important addition to, or even a guiding element for, 'new' entrepreneurship, recognising at the same time shortcomings of 'old' entrepreneurship. Opportunities with regard to sustainability are more complex than business opportunities which address a one dimensional problem, remove a serious pain point, or meet a significant want or need. Sustainability opportunities have, in their rudimentary form, more the character of 'wicked' problems. According to Rittel and Webber (1973), wicked problems, as opposed to tamed problems, are difficult to pin down, highly complex, and do not have definitive solutions. Because these problems have no closed form and concern complex systems in which cause and effect are uncertain or unknown, no simple solutions exist for them, or no solution at all; it is always a matter of compromise. There is no agreement on what the problem of sustainable development exactly is, neither can we decide whether proposed solutions are true or false in the longer run. On the one hand, we cannot propose definite solutions if we do not have a definite problem description. On the other hand, all proposed solutions remain finite and provisional compared to the complexity and depth of the sustainability problem itself. This complexity increases even further when we take into consideration that multiple stakeholders are involved with various (conflicting) frames, values and even ideologies with regard to sustainability (Peterson, 2009). In the case of sustainability, this involvement of multiple stakeholders even includes future generations with unknown and, in principle, unknowable interests and values. Therefore, not only does sustainable development involve various judgements of multiple stakeholders, but also these judgements will always be limited and finite by their very nature.

Accordingly, in order to benefit from entrepreneurial opportunities arising from sustainable development, it is not sufficient to develop policies for sustainability (Harris and Crane, 2002), create a specific sustainability department (Holton et al., 2010), embrace a code of conduct (Mamic, 2005), or implement a Sustainability Management System (SMS) (Holton et al., 2010). Each sustainability opportunity should be approached as a new challenge. What worked in the past, does not necessarily work for the future.

Dealing with these wicked problems, associated challenges and opportunities repeatedly require, primarily, specific capabilities. In the end these competencies are enacted, shaped and further developed by individual human actors (Wood, 1991). It is likely that these skills, knowledge and attitudes stem from the individual competencies of employees involved in sustainability challenges. Sustainable development asks for a focus on competencies and higher order thinking skills (Wals and Jickling, 2002).

Over the past few years, individual competencies for sustainable development have received much attention in sustainability literature. Significant progress has been made in conceptualising competencies for sustainable development, predominantly from the world of education (Barth et al., 2007; De Haan, 2006; Willard et al., 2010; Wiek et al., 2011). Based on these studies, Dentoni et al. (2012) have developed a framework consisting of seven competencies which are required for those who are actively involved in dealing with sustainability in their work environment. Based on a systematic review of the literature, they identified the following competencies for sustainable development in a business environment: systems-thinking competence, foresight-thinking competence, normative competence, embracing diversity and inter-disciplinarity, interpersonal competence, action competence and strategic management. These seven competencies are worked out in more detail below.

1. Systems-thinking competence. As explained, problems with regard to sustainable development (e.g., global warming, poverty and hunger, biodiversity decline) are complex and cannot be solved in a simple and unilateral way. With regard to sustainable development, systems-thinking is the ability to identify and analyse all relevant (sub)systems across different domains (people, planet, profit) and disciplines, including their boundaries. Furthermore, systems-thinking is the ability to understand and reflect upon the interdependency of these (sub) systems including cascading effects, inertia, and feedback loops and accompanying cultures.

2. Embracing diversity and interdisciplinarity. Problems of nonsustainable development can only be addressed through the collaboration of different scientific fields, different cultural traditions and approaches. The competence in interdisciplinary work is the ability to structure relations, spot issues and recognise the legitimacy of other viewpoints in business decision-making processes regarding environmental, social and economic issues, to involve all stakeholders and to maximize the exchange of ideas and learning across different groups (inside and outside the organisation) and different disciplines (interdisciplinarity) (De Haan, 2006; Ellis and Weekes, 2008; Wilson et al., 2006).

3. Foresighted thinking. The ability to collectively analyse, evaluate, and craft 'pictures' of the future in which the impact of local and/or short term decisions on environmental, social and economic issues is appreciated on the global/cosmopolitan scale and on the longer term (Wiek et al., 2011). This capacity includes skills in creativity, opportunity recognition, innovation and balancing of local/global and short-term/long-term perspectives (De Haan, 2006; Wiek et al., 2011).

4. Normative competence. Sustainable development is a normative concept - it doesn't describe the world as it is, but the way it should be - and the normative competence is the ability to map, apply and reconcile sustainability values, principles and targets. This competence enables the sustainable professional to assess and improve the (un-)sustainability of socialecological systems, based on such values and principles. The normative competence helps to ensure that managers, 
sustainable professionals and other employees are held accountable for the decisions made (Gibson, 2006; Grunwald, 2004; Wiek et al., 2011).

5. Action competence. Sustainable development cannot be achieved merely through state intervention, legislation, new technologies and efficient economies, but requires passive and active support from the population. Action competence is the ability to actively involve oneself in responsible actions to improve the sustainability of social-ecological systems (De Haan, 2006; Ellis and Weekes, 2008; Mogensen and Schnack, 2010; Schnack, 1996).

6. Interpersonal competence. The ability to motivate, enable, and facilitate collaborative and participatory sustainability activities and research. This competence domain includes skills in communicating, collaborating, negotiating, empathy and compassion (De Haan, 2006; Wiek et al., 2011).

7. Strategic management. The ability to collectively design projects, implement interventions, transitions, and strategies towards sustainable development practices. This domain involves skills in planning (design and implement interventions, transitions, and transformative governance strategies towards sustainability), organising (arranging tasks, people and other resources), leading (inspiring and motivating people) and controlling (measuring performance, evaluation of policies, programmes and action plans, and taking action) (De Haan, 2006; Wiek et al., 2011).

In the next section the methods are described, how these two, apparently different, sets of competencies relate to each other. To further answer the first research question: which competencies constitute the heart of entrepreneurship and sustainable development (i.e. sustainable entrepreneurship)? a qualitative study (study 1) was conducted among teachers of a specific higher education institute, a university of applied sciences. Additionally, to answer the following question: Which competencies for sustainable entrepreneurship can be clearly identified within the context of higher education, a quantitative study (study 2) was carried out among students of the same higher education institute (HEI).

\section{Method}

\subsection{Specific setting}

Our research was carried out in a university of applied sciences in the Netherlands (which can be compared internationally with technical/vocational and further education (TAFE)). Although it is one of the smaller universities of applied sciences (approximately 4,500 students, distributed over three locations, with about 450 employees), it is the largest with a 'green' curriculum in the Netherlands. This means that they offer programmes which focus on nature, environment, human and animal health, nutrition and food production. Entrepreneurship education arrived around 2005, and nowadays all bachelor programmes have a compulsory part in entrepreneurship education with increasing attention on sustainability. So students do not specifically choose an entrepreneurship programme, but encounter entrepreneurship throughout their programmes.

\subsection{Study 1: focus groups}

The first, qualitative, study included eight teachers from two locations of the university of applied sciences (four from each location). The teachers represented the specific programmes as well as courses with a focus on either entrepreneurship or sustainability. For instance one of the teachers was the coordinator of the Fair Trade Management course, whereas another teacher coordinated the Corporate Social Responsibility course and yet another teacher coordinated a course on Business Plan Writing. What is more, the teachers already knew each other through working together at the location and on specific projects. Focus group discussions were adapted as a method to discuss the generated lists of competencies for sustainable development and entrepreneurship as described in the theoretical framework, because of the newness and ambiguity of the topic. In both locations, three focus group discussions in sequence were held, with the same teachers, to give meaning to both lists of competencies and to collectively - with the researchers - explore similarities, differences, relationships and overlaps between these two sets of competencies. Each focus group discussion took about one and a half hours. The first session was aimed at establishing a common reference point and introducing both competence sets. The participating teachers were confronted with the two earlier described exemplary lists of competencies (see Table 1). These two lists (accompanied by a meaningful explanation from the researchers) were used as input for the discussion. The focal question was: 'do you recognise these competencies in your specific programme and/or course you teach?'

In the second session pairs of competencies from both sets that intuitively seem to be related to each other were discussed in more depth. The focal question to guide this session was 'where do these sets of competencies overlap?' Since one in-depth session appeared to be not enough to cover both sets, a third session was organised, similar to the second focus group meeting. In the focus groups one of the authors of this paper was the technical chairman (introducing questions, structuring the discussion), another author was the assistant who made notes and short in-between summaries of the discussion using mind-mapping software. The notes and mindmap summaries were used for further analysis in this study.

\subsection{Study 2: student questionnaire}

Participants in this second study were 231 international students from study programmes in rural and environmental management, animal husbandry, agri-business and management. The first four entrepreneurship competencies were integrated into the seven identified sustainable development competencies and operationalised into questions which covered not only the sustainability part but also the general entrepreneurship part based on the insight of study 1 . To avoid conceptual confusion, entrepreneurial self-efficacy (ESE) was treated as a separate variable and not integrated into the sustainability competencies. In order to avoid terms not commonly used in everyday speech or practice (e.g. typical jargon) two rounds of personal interviews with students were conducted to test whether the initial questionnaire was understandable for students from different study programmes. Questions were adapted based on remarks and discussion with 33 students in total. To measure the competencies, every student was asked to rate him-/herself according to his/her own opinion about

Table 1

Lists of entrepreneurship and sustainable development competencies.

\begin{tabular}{ll}
\hline Entrepreneurial competence & Sustainable development competence \\
\hline Opportunity competence & Systems thinking competence \\
Social competence & Embracing diversity and interdisciplinarity \\
Business competence & Foresighted thinking \\
Industry-specific competence & Normative competence \\
Entrepreneurial & Action competence \\
$\quad$ self-efficacy (ESE) & Interpersonal competence \\
& Strategic management competence \\
\hline
\end{tabular}


his/her performance at that moment for a criterion (i.e. one question) by giving a mark between 1 and $10(1=$ low and $10=$ high $)$ for every criterion. If some of the criteria had not been practiced in a study programme yet or learned in any other situation in the students' life (e.g. internship, work at home, holiday job), students were asked to show this by giving a low score for these criteria. Eventually this resulted in 42 new developed questions to measure action competence, embracing diversity and interdisciplinarity, foresighted thinking, interpersonal competence, normative competence, strategic management competence and systems thinking competence. The underlying questions for ESE are well described in entrepreneurship education literature and were adopted from existing scales (Liñán and Chen, 2009). ESE was measured using a five-point Likert scale. Additionally, other wellknown explanatory variables for entrepreneurship were added, namely gender ( $1=$ male, $2=$ female), year of entrance $(1=2008$, $4=2011)$, and whether or not students had parents who owned or managed a company ( $1=$ yes, $2=$ no). The final questionnaire was distributed among 231 students. The serious completion of the questionnaire was stimulated by the teachers involved (i.e. focus group participants) in their lectures. After returning, 211 questionnaires were suitable for further analysis. 51 percent of the participants were male and 49 percent female. More than 50 percent of the participants indicated that they had parents who owned-managed a company. The majority of the students entered their study programme either in 2010 (31 percent) or 2011 (58 percent). 16 percent of the students had no working experience, 71 percent had work experience as an employee (e.g. summer or holiday job), 6 percent had working experience as an entrepreneur, and a similar percentage had entrepreneurial working experience as well as employee experience. Reliabilities (Cronbach's Alpha) of each of the constructs used (e.g. systems thinking), as well as correlations between the constructs, were calculated. Additionally, exploratory factor analysis (EFA) was conducted using a Varimax rotation on the items which were created specifically for this study in order to identify common factors (i.e. latent competencies). As the formation of clear, distinct factors was an important objective, the EFA was conducted in an orthogonal rotation.

\section{Results}

\subsection{Study 1: focus groups}

Striking in the focus group discussions was the perceived overlap between both lists of competencies. Overlap was found in the focus groups on five main themes. Firstly, problems seem to be central in both competence lists of the entrepreneur and the professional actively engaged in sustainability. For the 'classic' entrepreneur, the solution of a significant problem is an important characteristic of superior business opportunities (e.g. opportunity competence). The entrepreneur writes a business plan in which a market problem is identified and a solution for this problem is formulated, i.e. a product or service with significant added value for the customer. Although different and often more complex sustainable development is, by definition, about problems and challenges. Just like the opportunity recognition of the entrepreneur, sustainable professionals perceive and interpret sustainability problems and construct adequate solutions (if possible) for these problems comprising social and environmental added value (e.g. foresighted thinking).

A second overlap between both lists is the importance of novelty and creativity. Novelty, innovativeness and creativity were often mentioned, in relation to entrepreneurial competence, by the teachers. Creativity is necessary to solve problems and add value. Opportunity recognition does not only consist in solutions for existing problems, but can also involve the finding of new and alternative solutions, problem finding, and the prediction or anticipation of future problems. All this presupposes a certain amount of creativity on the part of the nascent entrepreneur, especially in the early conceptualisation of the opportunity (e.g. opportunity competence). For sustainability, creativity and innovation are important as well. He/she is not only looking for alternative and more sustainable solutions to existing problems, but is also anticipating new problems, new developments and new solutions. The complexity of sustainability problems requires professionals who are able to look for new solutions and are able to open new perspectives (e.g. foresighted thinking).

A third overlap between both profiles is the self-involvement in entrepreneurship (e.g. opportunity competence) as well as sustainable development (e.g. action competence). It is not sufficient to explore new business opportunities and develop innovative products or services with significant added value. The entrepreneur should be able to exploit the business opportunity by starting a new venture or a new product-market combination in an established firm. In this respect, the entrepreneur is personally involved in the process of opportunity recognition and its exploitation. He/she can be seen as a self-starter with a strong personal drive, according to the teachers. Although in a different way, sustainable development also requires active and sometimes even idealistic individuals who want to change the world, who are willing to break conventions and try new things, start new initiatives, and who take the responsibility to solve problems in a sustainable way. The entrepreneurial as well as sustainable mind-set can therefore be seen as intrinsic, embodied and coming from the heart. It becomes visible in the form of inspiration, dreams, a vision, and in the associated aspirations of individual students. Rather than learning about these topics, students want to be involved in entrepreneurship or sustainability respectively, according to the teachers. In this respect, the exploitation of (business) opportunities by the entrepreneur as self-starter overlaps with the action competence of sustainability. Whereas the opportunity competence evolves through learning by doing - the start-up of a new venture - the action competence is about the active self-involvement in sustainable development.

A fourth overlap between both lists is that entrepreneurship competence, as well as sustainable development competence, is not only about initiating new things, but also about realising and improving projects and businesses. In order to be able to manage the new venture or new product market combination, the entrepreneur should be able to set objectives, arrange resources, lead people and control the performance to ensure the desired results (e.g. business competence). Just as a detailed business plan is necessary for starting a new venture, also sustainability projects need to be written in a conceivable way with a realistic planning, milestones etc. The same holds for the monitoring and evaluation of the project. In one of the focus group discussions, the term ecoefficiency was introduced to describe the added value of sustainable development. The professional involved in sustainable development should be able to write, execute and manage sustainability projects focussing on eco-efficiency. Therefore, she/he needs not only technical knowledge, but also superior knowledge of performance indicators, monitoring and evaluation processes, joint decision-making processes etc., i.e. strategic management competence. Typical managerial activities are thus clearly incorporated in the entrepreneurship and sustainability lists (i.e. business competence and strategic management respectively).

The fifth overlap noticed during the focus group discussions was the importance of engaging with others. Social competence is important for entrepreneurs to inspire and convince potential investors, inspire others and create winning teams. These social competencies overlap largely with the interpersonal competence of 
the sustainable development list, in which different viewpoints have to be bridged, and people have to also be convinced to break with existing conventions and embrace alternative solutions. The same overlap can be traced, if we take into account that sustainability involves various - sometimes conflicting - perspectives. This is especially apparent in those 'green' sectors which have a strong agricultural history (e.g. animal husbandry, dairy farming). Due to all sorts of modern agricultural challenges such as food safety, consumer awareness and multifunctional agriculture, students (who often inherit their parents' farm) increasingly need to engage with a heterogeneous group of (often very critical) stakeholders.

Besides these five sources of overlap between the entrepreneurship and sustainable development competence lists, there are also significant differences between both lists which have to be taken into account. Firstly, a stronger focus on individual accomplishments (as in 'drive', and 'self-efficacy') in the entrepreneurial competence list versus a more collective/societal aspiration in the sustainable development competence list. This difference does not have to be related to a difference in the value logics - i.e. a focus on economic added value versus social value - but with the individual motivation to excel. Secondly, a systems approach is essential for sustainability but is not at all recognised with regard to entrepreneurship competence. Thirdly, although personal integrity and moral strength are important for future entrepreneurs too, the normative competence is not central in the entrepreneurship competence list. For sustainability, the normative or ethical component of the list - doing the right thing instead of doing things right - is recognised, in the focus group, as crucial. Fourthly, although diversity and interdisciplinarity can be seen as a source of business opportunities too, embracing diversity and interdisciplinarity is not central to the entrepreneurship competence list. For sustainability, this competence is crucial, according to the teachers. It is stated that entrepreneurs have a smaller set of stakeholders to take into account, while sustainability is, by definition, about various stakeholders with their own interests, values and viewpoints. In general, entrepreneurship sector or industry specific competence is mostly highlighted, whereas sustainability requires not only cross-industry but also cross-sectoral knowledge. Cross-sector partnerships with governments or NGOs seem to be an important source for sustainability.

In conclusion, the competence lists from the entrepreneurship and SD literature have - according to the teachers of this particular applied university - significant overlap, although there are also important differences.

\subsection{Study 2: student questionnaire}

Study 1 resulted in a list of competencies relevant for sustainable entrepreneurship. The aim of study 2 was to identify clear and distinct factors (i.e. latent competencies) on the student level. As mentioned above, the total sample of study 2 contained 211 valid respondents.

\subsubsection{Tested constructs}

The reliability of the operationalised constructs were calculated based on the Cronbach's alphas. All alphas were above 0.70 (Table 2) and therefore considered as reliable.

Table 3 reveals that there is a positive relationship between the seven competencies: they correlate a small to medium extent with each other. Most interestingly, the meta-competence entrepreneurial self-efficacy (ESE) is significantly positive, correlated with six of the seven other competencies. The only competence which is not correlated with ESE is normative competence. There are also small negative correlations between some of the competencies
Table 2

Reliability scores of the original constructs.

\begin{tabular}{lll}
\hline Construct & $\begin{array}{l}\text { Cronbach's } \\
\text { alpha }\end{array}$ & $\begin{array}{l}\text { Number } \\
\text { of items }\end{array}$ \\
\hline Systems thinking competence (STC) & 0.85 & 6 \\
$\begin{array}{l}\text { Embracing diversity and } \\
\quad \text { interdisciplinarity (EDI) }\end{array}$ & 0.87 & 4 \\
Foresighted thinking (FTC) & 0.72 & 6 \\
Normative competence (NC) & 0.83 & 7 \\
Action competence (AC) & 0.85 & 8 \\
Interpersonal competence (IC) & 0.71 & 6 \\
Strategic management competence (SMC) & 0.90 & 5 \\
Entrepreneurial self-efficacy (ESE) & 0.79 & 7 \\
\hline
\end{tabular}

(including ESE) and gender and year of entrance; Table 3 suggests that males score themselves a bit higher on systems thinking, diversity competence and ESE, and those who started earlier with their studies tend to score themselves slightly higher on systems thinking competence and ESE as well. Students with parents who owned a company score only higher on entrepreneurial self-efficacy.

\subsubsection{Exploratory factor analysis: latent sustainable entrepreneurship competencies}

In the second study, the newly developed items for action competence, embracing diversity and interdisciplinarity, foresighted thinking, interpersonal competence, normative competence, strategic management competence and systems thinking competence were analysed to identify clear and distinct factors (i.e. latent competencies). Items with very low correlations (none of the items correlated extremely high) were removed from the dataset, resulting in a balanced final set consisting of 27 questions, with a satisfying Kaiser-Meyer-Olkin (KMO) measure of 0.88 and a significant Bartlett's test. Factor loadings less than 0.40 were excluded from interpretation. The final factor solution resulted in six interpretable factors (Table 4 ).

Overall, five of the seven original competencies reappear in the rotated factor solution. Only action competence and strategic management competence seem to mesh together into one new factor in the context of sustainable entrepreneurship in higher education.

\section{Discussion and conclusion}

Based on literature, a qualitative and a quantitative study, competencies from the domain of entrepreneurship and sustainability were integrated and operationalised in order to answer the postulated research questions. Based on the focus group discussions (study 1) with the HEI teachers it can be argued that both lists overlap with regard to 1 ) the centrality of (more or less complex) problems, 2) the importance of novelty and creativity, 3) the importance of self-involvement, 4) the combination of exploration and exploitation, and 5) the importance of engagement with significant others. Both competence lists also have clear differences. For instance, as the teachers indicated, the individual self-interest to excel in entrepreneurship competence can be contrasted with more collective/societal aspirations in sustainable development competence. Furthermore, sector/industry specific competence in entrepreneurship is different from the interdisciplinary focus in sustainability. Finally, some exemplary sustainability competencies are not at all addressed in entrepreneurship competence and vice versa. Normative competence for example clearly differentiated the entrepreneurship competence list from the sustainability list.

Accordingly, study 2 showed that normative competence in our sample did not correlate with general ESE. This supports the idea that general ESE and normative competence represent the two 
Table 3

Means and (inter)correlations of the competencies and other general variables.

\begin{tabular}{|c|c|c|c|c|c|c|c|c|c|c|c|}
\hline & M & (1) & $(2)$ & (3) & (4) & (5) & $(6)$ & (7) & (8) & (9) & $(10)$ \\
\hline (1) Systems thinking competence & 6.10 & - & & & & & & & & & \\
\hline (2) Embracing diversity and interdisciplinarity & 5.93 & $0.54^{* *}$ & - & & & & & & & & \\
\hline (3) Foresighted thinking & 6.44 & $0.61^{* *}$ & $0.51^{* *}$ & - & & & & & & & \\
\hline (4) Normative competence & 6.35 & $0.47^{* *}$ & $0.56^{* *}$ & $0.50^{* *}$ & - & & & & & & \\
\hline (5) Action competence & 5.60 & $0.44^{* *}$ & $0.41^{* *}$ & $0.43^{* *}$ & $0.48^{* *}$ & - & & & & & \\
\hline (6) Interpersonal competence & 6.70 & $0.20^{* *}$ & $0.19^{* *}$ & $0.33^{* *}$ & $0.32^{* *}$ & $0.38^{* *}$ & - & & & & \\
\hline (7) Strategic management competence & 5.57 & $0.44^{* *}$ & $0.49^{* *}$ & $0.43^{* *}$ & $0.45^{* *}$ & $0.64^{* *}$ & $0.39^{* *}$ & - & & & \\
\hline (8) Entrepreneurial Self-Efficacy & 2.97 & $0.31^{* *}$ & $0.19^{* *}$ & $0.30^{* *}$ & 0.12 & $0.17^{* *}$ & $0.20^{* *}$ & $0.32^{* *}$ & - & & \\
\hline (9) Year of entrance & 3.49 & $-0.15^{*}$ & -0.04 & -0.10 & 0.04 & -0.06 & -0.07 & -0.10 & $-0.15^{*}$ & - & \\
\hline (10) Parents owner-manager & 1.47 & -0.08 & 0.00 & -0.06 & 0.02 & 0.09 & 0.05 & -0.02 & $-0.24^{* *}$ & 0.07 & - \\
\hline (11) Gender & 1.49 & $-0.25^{* *}$ & $-0.15^{*}$ & -0.04 & -0.07 & 0.06 & 0.07 & -0.04 & $-0.16^{*}$ & $-0.21^{* *}$ & 0.11 \\
\hline
\end{tabular}

Note. $\mathrm{M}=$ mean, $N=211 .{ }^{*} p<.05,{ }^{* *} p<.01$.

boundaries of the sustainable entrepreneurship competence spectrum. Theoretically, normative competence seems to go a level deeper in terms of reflection and awareness, when actually dealing with sustainability dilemmas, than the other competencies which have a more prominent action-orientation. As Blok et al. (2012) argue, the normative competence has to be understood as the ability to develop, negotiate and reconcile norms and targets together with internal and external stakeholders, without

Table 4

Rotated factor solution: underlying items, original domains and factor loadings $(n=211)$.

\begin{tabular}{|c|c|c|c|c|c|c|c|c|}
\hline NR & Item description & Original & 1 & 2 & 3 & 4 & 5 & 6 \\
\hline $\mathrm{X} 1$ & $\begin{array}{l}\text { When it comes to achieving particular goals in relation to sustainability } \\
\text { I know whom to involve. }\end{array}$ & SMC & 0.75 & 0.29 & 0.12 & 0.04 & -0.11 & 0.18 \\
\hline $\mathrm{X} 2$ & $\begin{array}{l}\text { I am able to use a strategic way of working in sustainability related } \\
\text { projects (designing, testing, implementing, evaluating). }\end{array}$ & SMC & 0.75 & 0.06 & 0.15 & 0.13 & 0.16 & 0.16 \\
\hline X3 & I am able to monitor the sustainability performance of a company. & SMC & 0.75 & 0.20 & 0.17 & 0.00 & 0.19 & 0.22 \\
\hline $\mathrm{X} 4$ & $\begin{array}{l}\text { If I want to reach goals in relation to sustainability, I know which steps } \\
\text { should be taken to be successful. }\end{array}$ & SMC & 0.74 & 0.26 & 0.31 & 0.12 & -0.05 & 0.10 \\
\hline X5 & I am very good at identifying opportunities for sustainable development. & $\mathrm{AC}$ & 0.69 & 0.09 & 0.09 & 0.25 & 0.40 & 0.00 \\
\hline X6 & $\begin{array}{l}\text { I am able to motivate higher management in a company to invest in } \\
\text { sustainability. }\end{array}$ & $\mathrm{AC}$ & 0.65 & 0.19 & 0.14 & 0.38 & 0.11 & -0.10 \\
\hline $\mathrm{X} 7$ & $\begin{array}{l}\text { I know how social, environmental or societal challenges can be turned } \\
\text { into opportunities for an organisation/company. }\end{array}$ & $\mathrm{AC}$ & 0.58 & 0.13 & 0.21 & 0.38 & 0.08 & -0.10 \\
\hline $\mathrm{X} 8$ & I challenge non-sustainable ways of working in a company. & AC & 0.53 & -0.01 & 0.08 & 0.09 & 0.43 & 0.13 \\
\hline X9 & $\begin{array}{l}\text { I am able to actively involve stakeholders and experts from other } \\
\text { disciplines in addressing sustainability issues. }\end{array}$ & EDI & 0.24 & 0.83 & 0.15 & 0.19 & 0.13 & -0.03 \\
\hline X10 & $\begin{array}{l}\text { I use the experiences, activities and values of various relevant } \\
\text { stakeholders in addressing sustainability issues. }\end{array}$ & EDI & 0.15 & 0.79 & 0.15 & 0.10 & 0.18 & 0.25 \\
\hline X11 & $\begin{array}{l}\text { I am able to explain the importance of involving local stakeholders } \\
\text { (e.g. in recruitment) for a company. }\end{array}$ & EDI & 0.18 & 0.76 & 0.14 & 0.34 & -0.04 & -0.09 \\
\hline $\mathrm{X} 12$ & $\begin{array}{l}\text { I am able to bring together economic, social and environmental conflicts } \\
\text { of interest. }\end{array}$ & EDI & 0.28 & 0.59 & 0.25 & 0.01 & 0.39 & 0.11 \\
\hline X13 & $\begin{array}{l}\text { I am able to identify the key operations of a company that have a negative } \\
\text { impact on the environment or society. }\end{array}$ & STC & 0.16 & 0.15 & 0.79 & 0.16 & 0.10 & 0.14 \\
\hline X14 & $\begin{array}{l}\text { I am able to identify key aspects of production chains and agricultural } \\
\text { eco-systems. }\end{array}$ & STC & 0.17 & 0.18 & 0.75 & 0.04 & 0.15 & 0.05 \\
\hline X15 & $\begin{array}{l}\text { I am able to analyse strengths and weaknesses of production chains and } \\
\text { propose improvements to reduce the negative effects on the } \\
\text { environment or society. }\end{array}$ & STC & 0.18 & 0.11 & 0.68 & 0.30 & 0.14 & 0.02 \\
\hline X16 & $\begin{array}{l}\text { I am able to construct and consider different directions for sustainability } \\
\text { in the future. }\end{array}$ & FT & 0.30 & 0.08 & 0.52 & 0.19 & 0.50 & 0.08 \\
\hline X17 & $\begin{array}{l}\text { I am able to integrate social, environmental and societal issues into } \\
\text { future plans of a company. }\end{array}$ & STC & 0.28 & 0.32 & 0.50 & 0.34 & 0.18 & 0.07 \\
\hline X18 & $\begin{array}{l}\text { I am able to apply norms, values, targets and principles of sustainability } \\
\text { to my own practice. }\end{array}$ & $\mathrm{NC}$ & 0.16 & 0.22 & 0.13 & 0.72 & 0.27 & 0.16 \\
\hline X19 & I know what is seen as 'good sustainable practice' in my field of study. & $\mathrm{NC}$ & 0.24 & 0.14 & 0.28 & 0.71 & 0.07 & 0.14 \\
\hline $\mathrm{X} 20$ & $\begin{array}{l}\text { I know how to explain the decisions a company has made concerning } \\
\text { sustainability. }\end{array}$ & $\mathrm{NC}$ & 0.24 & 0.17 & 0.29 & 0.65 & 0.16 & 0.18 \\
\hline $\mathrm{X} 21$ & $\begin{array}{l}\text { In analysing and evaluating scenarios for action, I take both the impact } \\
\text { on the local and the global scale into consideration. }\end{array}$ & FT & 0.20 & 0.47 & 0.26 & 0.02 & 0.59 & 0.05 \\
\hline $\mathrm{X} 22$ & $\begin{array}{l}\text { I am able to identify risks and opportunities inherent in present and } \\
\text { future developments. }\end{array}$ & FT & 0.16 & 0.16 & 0.41 & 0.24 & 0.56 & -0.12 \\
\hline $\mathrm{X} 23$ & $\begin{array}{l}\text { In analysing and evaluating scenarios for action, I take the impact on } \\
\text { the short as well as the long term into consideration. }\end{array}$ & FT & 0.07 & 0.19 & 0.27 & 0.37 & 0.54 & -0.03 \\
\hline $\mathrm{X} 24$ & $\begin{array}{l}\text { I am willing to take initiative to make improvements in my own practice } \\
\text { based on norms, values, targets and principles of sustainability. }\end{array}$ & $\mathrm{NC}$ & 0.06 & 0.07 & 0.01 & 0.47 & 0.52 & 0.32 \\
\hline X25 & $\begin{array}{l}\text { In a personal conflict, I am able to take the others' perspective and really } \\
\text { understand his or her point of view. }\end{array}$ & IC & 0.00 & -0.04 & 0.08 & 0.07 & 0.13 & 0.82 \\
\hline X26 & I am patient and sensitive to someone who "lets off steam" in complex issues. & IC & 0.12 & -0.02 & 0.04 & 0.17 & 0.00 & $\mathbf{0 . 7 7}$ \\
\hline $\mathrm{X} 27$ & I am able to feel to what extent stakeholders are willing to cooperate in a project. & IC & 0.23 & 0.23 & 0.05 & 0.05 & -0.05 & 0.66 \\
\hline
\end{tabular}

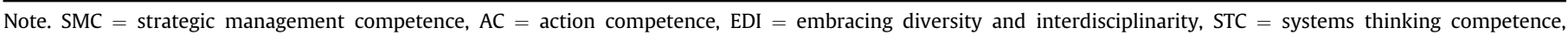
$\mathrm{FT}=$ foresighted thinking, $\mathrm{NC}=$ normative competence and IC $=$ interpersonal competence. The values in bold are the highest factor loadings ( $>0.40$ ). 
embracing any given norm but based on the good character of the one who is involved in sustainability issues.

Furthermore strategic management competence and action competence did not emerge as two separate constructs from the student sample. From a practical point of view this makes sense since both competencies represent the actual pursuit of a sustainability opportunity and the turning of it into a concrete project; both require active involvement of the individual. Nonetheless, we are, at this exploratory stage, reluctant to put these two competencies together based on this first result. Further research is necessary to see whether this is indeed of added value.

Although the results of both studies are promising, they only reflect one particular higher educational institute and a limited number of teachers and students. The student sample was large enough to explore the data by means of a factor analysis, but for more advanced analyses additional data is required. To start, to be more sure about convergent and discriminant validity of the measured variables and identified constructs, and allow for testing of competing models (e.g. a framework in which action and strategic management competence are combined) confirmatory factor analyses should be carried out on a larger sample. Secondly, data on the sustainable entrepreneurship profile was only collected amongst teachers and students. Whether practicing sustainable entrepreneurs or sustainable venture capitalists also recognise themselves in these competencies was beyond the scope of this study. However, recent work suggests that these competencies are viewed as highly important by practitioners (Miller et al., 2012). To be certain, similar to the focus groups with teachers, focus groups could be conducted with sustainable entrepreneurs and/or sustainable venture capitalists. This would also create the possibility of exploring the boundaries of sustainable entrepreneurship (e.g. ESE and normative competence) more carefully. Finally, to get a better grip on the external validity of the developed competence profile, the profile could be correlated with other, more tangible, performance indicators for the different competencies.

As stated in the introduction, it is unlikely that these competencies emerge overnight. This raises the question of to what extent these competencies can be developed and, if so, whether the different sustainable entrepreneurship competencies should be treated equally in higher education. In order to answer the former question, the framework could be used to monitor competence development over time. This could be done in interventions (e.g. a specific programme), or over longer periods of time (also after leaving school and starting as a professional/entrepreneur). In entrepreneurship education research these kinds of studies generate at present very interesting insights (Fayolle et al., 2006; Karimi et al., 2012). To answer the latter, whether all competencies should be treated equally, this study suggests that some of the competencies are more distinctive for sustainable entrepreneurship than others. This view is in line with a recent study on education for social entrepreneurship (Miller et al., 2012). Whether or not these competencies should be dealt with more intensively in education is open for debate. What should be avoided at all cost is that these competencies are 'trained' separately; as our studies show, all constructs correlate with each other, not only empirically, but also in practice. Nonetheless, more research about the 'how' question is necessary to further support teachers in their effort to design competence-based curricula, courses and authentic learning activities aimed at learning for sustainable entrepreneurship.

To conclude, we started the article with the notion that companies are in need of owners, managers and staff-members who are able to recognise sustainability as an opportunity. However, entrepreneurship, thus opportunity recognition, is often viewed as unsustainable, neglecting the potential of entrepreneurship for contributing and providing solutions for sustainable development.
Theoretically combining these worlds resulted in a perspective in which sustainable development is a rich, but complex, source for entrepreneurial opportunities. Walking this path requires individual competencies, both from the domain of entrepreneurship and sustainability. The results of the qualitative study among teachers suggests that when sustainability becomes a specific area for entrepreneurial opportunities, and associated competencies from both domains are combined, one could distinguish competencies which overlap between both domains, competencies with distinct differences due to the specific context of sustainability, and competencies which are unique for the domain of sustainability. Accordingly, study 2 showed that five of the seven original competencies (embracing diversity and interdisciplinarity, foresighted thinking, interpersonal competence, normative competence and systems thinking competence) reappear in the quantitative study. Only action competence and strategic management competence seem to mesh together into one new factor in the context of sustainable entrepreneurship in higher education. Altogether, at this point, the developed competence framework, associated with assessable indicators, provide researchers as well as teachers with stepping stones for sustainable entrepreneurship education in school-based environments.

\section{Acknowledgements}

The authors would like to thank all the teachers who participated in the focus groups, the students who were willing to review our preliminary questionnaires, Suzanne Gotschalk in particular who helped us to collect the data in time and DAFNE (Dutch Agrofood Network of Entrepreneurship) for financing this study. Furthermore we would like to thank the anonymous reviewers for their helpful comments on earlier version of this manuscript.

\section{References}

Accenture, 2010. A New Era of Sustainability: UN Global Compact-accenture CEO Study. Available at: www.unglobalcompact.org

Ahmad, N.H., Wilson, C., Kummerow, L., 2011. A cross-cultural insight into the competency-mix of SME entrepreneurs in Australia and Malaysia. International Journal of Business and Management Science 4, 33-50.

Aldrich, H.E., Zimmer, C., 1986. Entrepreneurship Through Social Networks. University of Illinois at Urbana-Champaign's Academy for Entrepreneurial Leadership Historical Research Reference in Entrepreneurship.

Ardichvili, A., Cardozo, R., Ray, S., 2003. A theory of entrepreneurial opportunity identification and development. Journal of Business Venturing 18, 105-123.

Arenius, P., Clercq, D.D., 2005. A network-based approach on opportunity recognition. Small Business Economics 24, 249-265.

Bandura, A., 1982. Self-efficacy mechanism in human agency. American Psychologist 37, 122-147.

Baron, R.A., Ensley, M.D., 2006. Opportunity recognition as the detection of meaningful patterns: evidence from comparisons of novice and experienced entrepreneurs. Managament Sciene 52, 1331-1344.

Baron, R.A., Markman, G.D., 2003. Beyond social capital: the role of entrepreneurs' social competence in their financial success. Journal of Business Venturing 18, 41-60.

Baron, R.A., Tang, J., 2009. Entrepreneurs' social skills and new venture performance: mediating mechanisms and cultural generality. Journal of Management $35,282-306$

Barth, M., Godemann, J., Rieckman, M., Stoltenberg, U., 2007. Developing key competences for sustainable development in higher education. International Journal of Sustainability in Higher Education 8, 416-430.

Baum, J.R., Locke, E.A., 2004. The relationship of entrepreneurial traits, skill, and motivation to subsequent venture growth. Journal of Applied Psychology 89, 587-598.

Baum, J.R., Locke, E.A., Smith, K.G., 2001. A multidimensional model of venture growth. The Academy of Management Journal 44, 292-303.

Blok, V., Gremmen, B., Wesselink, R., 2012. Dealing with the ‘Wicked Problem' of Sustainability. The Necessity of Virtuous Competence. Internal working paper. Wageningen University,.

Buysse, K., Verbeke, A., 2003. Proactive environmental strategies: a stakeholder management perspective. Strategic Management Journal 24, 453-470.

Camuffo, A., Gerli, F., Gubitta, P., 2012. Competencies matter: modeling effective entrepreneurship in northeast of Italy small firms. Cross Cultural Management $19,48-66$. 
Chandler, G.N., Jansen, E., 1992. The founder's self-assessed competence and venture performance. Journal of Business Venturing 7, 223-236.

Chiasson, M., Saunders, C., 2005. Reconciling diverse approaches to opportunity research using the structuration theory. Journal of Business Venturing 20, 747-767.

Colombo, M.G., Grilli, L., 2005. Founders' human capital and the growth of new technology-based firms: a competence-based view. Research Policy 34, 795-816.

Companys, Y., McMullen, J., 2007. Strategic entrepreneurs at work: the nature, discovery, and exploitation of entrepreneurial opportunities. Small Business Economics 28, 301-322.

Cope, J., 2005. Toward a dynamic learning perspective of entrepreneurship. Entrepreneurship Theory and Practice 29, 373-397.

Corbett, A.C., 2005. Experiential learning within the process of opportunity identification and exploitation. Entrepreneurship Theory and Practice 29, 473-491.

Dale, A., Newman, L., 2005. Sustainable development, education and literacy. International Journal Sustainable Higher Edcuation 6, 351-362.

De Haan, G., 2006. The BLK ' 21' programme in Germany: a ' Gestaltungskompetenz' based model for education for sustainable development. Environmental Education Research 12, 19-32.

Dentoni, D., Blok, V., Lans, T., Wesselink, R., 2012. Developing human capital for agri-food firms' multi-stakeholder interactions. International Food and Agribusiness Management Review 15, 61-68.

DeTienne, D.R., Chandler, G.N., 2004. Opportunity identification and its role in the entrepreneurial classroom: a pedagogical approach and empirical test. Academy of Management Learning \& Education 3, 242-257.

Dimov, D., 2007. Beyond the single-person, Single-insight attribution in understanding entrepreneurial opportunities. Entrepreneurship Theory and Practice 31, 713-731.

Dunphy, D., Griffiths, A., Benn, S., 2007. Organizational Change for Corporate Sustainability, second ed. Routledge, London/New York.

Dutta, D.K., Crossan, M.M., 2005. The nature of entrepreneurial opportunities: understanding the process using the 4I organizational learning framework. Entrepreneurship Theory and Practice 29, 425-449.

Ellis, G., Weekes, T., 2008. Making sustainability 'real': using group-enquiry to promote education for sustainable development. Environmental Education Research 14, 482-500.

Fayolle, A., Gailly, B., Lassas-Clerc, N., 2006. Assessing the impact of entrepreneurship education programmes: a new methodology. Journal of European Industrial Training 30, 701-720.

Gaglio, C.M., Katz, J.A., 2001. The psychological basis of opportunity identification: entrepreneurial alertness. Small Business Economics 16, 95-111.

Gartner, W.B., 1989. 'Who is an entrepreneur?' is the wrong question. Entrepreneurship Theory and Practice 13, 47-68.

Gibb, A., 2002. Creating conducive environments for learning and entrepreneurship: living with, dealing with, creating and enjoying uncertainty and complexity. Industry and Higher Education 16, 135-148.

Gibson, R., 2006. Sustainability assessment: basic components of a practical approach. Impact Assessment and Project Appraisal 24, 170-182.

Grunwald, A., 2004. Strategic knowledge for sustainable development: the need for reflexivity and learning at the interface between science and society. IJFIP 1 (12), 150-167.

Guo, K.L., 2009. Core competencies of the entrepreneurial leader in health care organizations. Health Care Manager 28, 19-29.

Gurău, C., 2006. Bio-entrepreneurship in different economic systems: a comparative analysis of bio-entrepreneurs' profile in UK, France and Germany. International Journal of Biotechnology 8 (3-4), 169-186.

Harris, L.C., Crane, A., 2002. The greening of organizational culture: management views on the depth, degree and diffusion of change. Journal of Organizational Change Management 15, 214-234.

Holton, I., Glass, J., Price, A.D.F., 2010. Managing for sustainability: findings from four company case studies in the UK precast concrete industry. Journal of Cleaner Production 18, 152-160.

Karimi, S., Biemans, H.J.A., Lans, T., Mulder, M., Chizari, M., 2012. The Role of Entrepreneurship Education in Developing Students' Entrepreneurial Intentions. Available at SSRN: http://ssrn.com/abstract=2152944.

Klewitz, J., Hansen, E.G., 2011. Sustainability-Oriented Innovation in SMEs: a Systematic Literature Review of Existing Practices and actors involved. ISPIM Conference (International Society for Professional Innovation Management). In: Sustainability in Innovation: Innovation Management Challenges, June 2011. Available at SSRN: http://ssrn.com/abstract=1858664.

Lambrechts, W., Mulà, I, Ceulemans, K., Molderez, I., Gaeremynck, V., 2013. The integration of competences for sustainable development in higher education: analysis of bachelor programs in management. Journal of Cleaner Production 48, 65-73.

Lans, T., Hulsink, W., Baert, H., Mulder, M., 2008. Entrepreneurship education and training in a small business context: insights from the competence-based approach. Journal of Enterprising Culture 16, 363-383.

Lans, T., Verstegen, J., Mulder, M., 2011. Analysing, pursuing and networking: a validated three-factor framework for entrepreneurial competence from a small business perspective. International Small Business Journal 29, 695-713.

Liñán, F., Chen, Y.-W., 2009. Development and cross-cultural application of a specific instrument to measure entrepreneurial intentions. Entrepreneurship Theory and Practice 33, 593-617.
Lumpkin, G.T., Dess, G.G., 1996. Clarifying the entrepreneurial orientation construct and linking it to performance. The Academy of Management Review 21, 135-172.

Lumpkin, G.T., Dess, G.G., 2001. Linking two dimensions of entrepreneurial orientation to firm performance: the moderating role of environment and industry life cycle. Journal of Business Venturing 16, 429-451.

Le Deist, F., Winterton, J., 2005. What is competence?. Human Resource Development International 8, 27-46.

Mackey, T.A., 2005. Planning your nursing business. Journal of the American Academy of Nurse Practitioners 17, 501-505.

Málovics, G., Csigéné, N.N., Kraus, S., 2006. The role of corporate social responsibility in strong sustainability. The Journal of Socio-economics 37, 907-918.

Mamic, I., 2005. Managing global supply chain: the sports footwear, apparel and retail sectors. Journal of Business Ethics 59, 81-100.

Man, T.W.Y., Lau, T., Chan, K.F., 2002. The competitiveness of small and medium enterprises: a conceptualization with focus on entrepreneurial competencies. Journal of Business Venturing 17, 123-142.

Markman, G.D., 2007. Entrepreneurs' competencies. In: Baum, J.R., Frese, M. Baron, R.A. (Eds.), The Psychology of Entrepreneurship, SIOP Organisational Frontier Series. Lawrence Erlbaum, New Jersey, pp. 67-92.

Miller, T.L., Wesley, C.L., Williams, D.E., 2012. Educating the minds of caring hearts: comparing the views of practitioners and educators on the importance of social entrepreneurship competencies. Academy of Management Learning \& Education 11, 349-370.

Mitchelmore, S., Rowley, J., 2010. Entrepreneurial competencies: a literature review and development agenda. International Journal of Entrepreneurial Behaviour and Research 16, 92-111.

Mogensen, F., Schnack, K., 2010. The action competence approach and the 'new' discourses of education for sustainable development, competence and quality criteria. Environmental Education Research 16, 59-74.

Mulder, M., 2012. Competence-based education and training. The Journal of Agricultural Education and Extension 18, 305-314.

Muñoz, C.C.A., Mosey, S., Binks, M., 2011. Developing opportunity-identification capabilities in the Classroom: visual evidence for changing mental frames. Academy of Management Learning \& Education 10, 277-295.

Nuthall, P.L., 2006. Determining the important management skill competencies: the case of family farm business in New Zealand. Agricultural Systems 88, 429-450.

Obschonka, M., Silbereisen, R.K., Schmitt-Rodermund, E., 2011a. Successful entrepreneurship as developmental outcome a path model from a lifespan perspective of human development. European Psychologist 16, 174-186.

Obschonka, M., Silbereisen, R.K., Schmitt-Rodermund, E., Stuetzer, M., 2011b. Nascent entrepreneurship and the developing individual: early entrepreneurial competence in adolescence and venture creation success during the career. Journal of Vocational Behavior 79, 121-133.

Phelan, C., Sharpley, R., 2012. Exploring entrepreneurial skills and competencies in farm tourism. Local Economy 27, 103-118.

Peterson, C., 2009. Transformational supply chains and the 'wicked problem' of sustainability: aligning knowledge, innovation, entrepreneurship, and leadership. Journal of Chain and Network Science 9, 71-82.

Pittaway, L., Cope, J., 2007. Entrepreneurship education: a systematic review of the evidence. International Small Business Journal 25, 479-510.

Rauch, A., Frese, M., 2007. Born to be an entrepreneur? Revisiting the personality approach to entrepreneurship. In: Baum, J.R., Frese, M., Baron, R.A. (Eds.), The Psychology of Entrepreneurship. Lawrence Erlbaum, New Jersey, pp. 41-65.

Rittel, H.W.J., Webber, M.M., 1973. Dilemmas in a general theory of planning. Policy Sciences 4, 155-169.

Rowe, D., 2007. Education for a sustainable future. Science 317, 323-324.

Rubino, L., Freshman, B., 2005. Developing entrepreneurial competencies in the healthcare management undergraduate classroom. The Journal of Health Administration Education 22, 399-416.

Sadler-Smith, E., Hampson, Y., Chaston, I., Badger, B., 2003. Managerial behavior, entrepreneurial style, and small firm performance. Journal of Small Business Management 41, 47-67.

Schaltegger, S., Wagner, M., 2011. Sustainable entrepreneurship and sustainability innovation: categories and interactions. Business Strategy and the Environment 20, 222-237.

Schumpeter, J.A., 1934. The Theory of Economic Development. Harvard, Cambridge, MA.

Schnack, K., 1996. Internationalisation, democracy and environmental education. In: Breiting, S., Nielsen, K. (Eds.), Environmental Education Research in the Nordic Countries: Proceedings from the Research Centre for Environmental and Health Education. The Royal Danish School for Educational Studies, Copenhagen, pp. 7-19.

Shane, S., Venkataraman, S., 2000. The promise of enterpreneurship as a field of research. The Academy of Management Review 25, 217-226.

Teece, D.J., Pisano, G., Shuen, A., 1997. Dynamic capabilities and strategic management. Strategic Management Journal 18, 509-533.

Ucbasaran, D., Westhead, P., Wright, M., 2008. Opportunity identification and pursuit: does an Entrepreneur's human capital matter? Small Business Economics 30, 153-173.

Wagener, S., Gorgievski, M., Rijsdijk, S.A., 2010. Businessman or host? Individual differences between entrepreneurs and small business owners in the hospitality industry. Service Industries Journal 30, 1513-1527.

Wals, A.E.J., 2010. Mirroring, Gestaltswitching and transformative social learning: stepping stones for developing sustainability competence. International Journal of Sustainability in Higher Education 11, 380-390. 
Wals, A.E.J., Jickling, B., 2002. "Sustainability" in higher education: from doublethink and newspeak to critical thinking and meaningful learning. Higher Education Policy 15, 121-131.

Wesselink, R., de Jong, C., Biemans, H., 2010. Aspects of competence-based education as footholds to improve the connectivity between learning in school and in the workplace. Vocations and Learning 3, 19-38.

Wiek, A., Withycombe, L., Redman, C.L., 2011. Key competencies in sustainability: a reference framework for academic program development. Sustainability Science 6, 203-218.

Willard, M., Wiedmeyer, C., Warren Flint, R., Weedon, J.S., Woodward, R., Feldman, I., Edwards, M., 2010. The sustainability professional: 2010 competency survey report. Environmental Quality Management, 49-83.

Wilson, A., Lenssen, G., Hind, P., 2006. Leadership Qualities and Management Competencies for Corporate Responsibility. Ashridge, United Kingdom.
Wood, D.J., 1991. Corporate social performance revisited. Academy of Management Review 16, 691-718.

World Commission on Environment and Development, 1987. Our Common Future. Oxford UP, Oxford.

Wu, W.W., 2009. A competency-based model for the success of an entrepreneurial start-up. WSEAS Transactions on Business and Economics 6, 279291.

WWF International, 2006. Living Planet Report 2006. (Gland, Switzerland)

Zadek, S., 2004. The path to corporate responsibility. Harvard Business Review 12, 125-132.

Zahra, S.A., Gedajlovic, E., Neubaum, D.O., Shulman, J.M., 2009. A typology of social entrepreneurs: motives, search processes and ethical challenges. Journal of Business Venturing 24, 519-532.

Zapalska, A.M., Brozik, D., Rudd, D., 2004. Characteristics of polish entrepreneurship in the tourism and hospitality industry. Tourism 52, 215-234. 